\title{
PERBEDAAN PENGARUH ANTARA MOBILISASI SARAF DAN MYOFACIAL RELEASE TERHADAP PENURUNAN NYERI PADA PASIEN CARPAL TUNNEL SYNDROME
}

\author{
Budi Utomo, Yulianto Wahyono \\ Kementerian Kesehatan Politeknik Kesehatan Surakarta Jurusan Fisioterapi
}

\begin{abstract}
Nerve Mobilization, Myofacial Release, Carpal Tunnel Syndrome. Carpal tunnel syndrome (CTS) is defined with signs and symptoms resulting from compression of the median nerve at the wrist. CTS lead to discomfort and pain, limited daily activities, sleep deprivation and the inability to work. Nerve mobilization is manipulative technique in which the nerve tissue is moved and stretched out both motions relative to the surrounding (interface mechanical) or with the development of tension. Myofascial Release (MFR) refers to massage techniques, instructions for stretching the fascia and releasing bonds between fascia and integument, muscles, bone, with the aim to relieve pain, increase range of motion and balance the body. Some research concluded the difference in the length of time the treatment is with a shorter time can produce significant pain reduction. The aim of this study was to determine the effect of the difference between the provision of nerve mobilization and myofacial release to the reduction of pain in patients with carpal tunnel syndrome. This research is a quasi experimental study with two group pre test and post test control design. The subjects were all patients diagnosed with carpal tunnel syndrome who came to the clinic physiotherapy Dr. Moewardi Surakarta hospital who met the inclusion criteria, exclusion and drop out. Number of research subjects in group I, amounting to 8 people and group II amounted to 7 people. Group I was treated nerve mobilization and group II were treated Myofacial release. Treatment was given 2 times per week for 3 weeks. Results: (1) mobilization of the nerve may reduce pain in patients with CTS ( $p=0.012)$, (2) MFR can reduce a patient's pain CTS $(p=0.018)$, (3) there is no difference between mobilization nerves and MFR to reduce pain CTS patients $(p=0.189)$.
\end{abstract}

Keywords: Nerve Mobilization, Myofacial Release, Carpal Tunnel Syndrome

Abstrak : Mobilisasi Saraf, Myofacial Release, Carpal Tunnel Syndrome. Carpal tunnel syndrome (CTS) diartikan dengan tanda dan gejala yang dihasilkan dari kompresi saraf medianus pada pergelangan tangan. CTS mengakibatkan rasa tidak nyaman dan nyeri, terbatasnya aktifitas keseharian, kurang tidur dan ketidakmampuan untuk bekerja. Mobilisasi saraf adalah teknik manipulatif dimana jaringan saraf digerakkan dan diulurkan baik gerakan yang relatif terhadap sekitarnya (interface yang mekanis) atau dengan pengembangan ketegangan Myofascial release (MFR) mengacu pada teknik pijat, petunjuk untuk peregangan fasia dan melepaskan ikatan antara fasia dan integumen, otot, tulang, dengan tujuan untuk menghilangkan rasa sakit, meningkatkan jangkauan gerak dan menyeimbangkan tubuh. Beberapa hasil penelitian dapat disimpulkan adanya perbedaan lama waktu perlakuan apakah dengan waktu yang lebih singkat bisa menghasilkan penurunan nyeri yang signifikan. Tujuan penelitian ini 
adalah untuk mengetahui perbedaan pengaruh antara pemberian mobilisasi saraf dan myofacial release terhadap penurunan nyeri pada pasien carpal tunnel syndrome. Penelitian ini adalah penelitian quasi experiment dengan two group pre test and post test control design. Subyek penelitian adalah semua pasien yang didiagnosis carpal tunnel syndrome yang datang ke klinik fisioterapi RSUD Dr. Moewardi Surakarta yang memenuhi kriteria inklusi, eksklusi dan drop out. Jumlah subyek penelitian pada kelompok I berjumlah 8 orang dan kelompok II berjumlah 7 orang. Kelompok I diberi perlakuan mobilisasi saraf dan kelompok II diberi perlakuan Myofacial release. Perlakuan diberikan 2 kali per minggu selama 3 minggu. Hasil (1) mobilisasi saraf dapat menurunkan nyeri pada pasien CTS ( $\mathrm{p}=0,012)$, (2) MFR dapat menurunkan nyeri pasien CTS ( $\mathrm{p}=0,018)$, (3) tidak terdapat perbedaan antara mobilisasi saraf dan MFR untuk menurunkan nyeri pada pasien CTS $(\mathrm{p}=0,189)$.

Kata Kunci : Mobilisasi Saraf, Myofacial Release, Carpal Tunnel Syndrome

\section{PENDAHULUAN}

Teknologi dan industri ini berkembang untuk memenuhi kebutuhan dan keinginan manusia agar dalam kehidupan dapat lebih mudah berkomunikasi ataupun melakukan sesuatu. Namun tanpa disadari, perkembangan teknologi dan industri justru dapat menimbulkan penyakit. Salah satu penyakit yang timbul akibat kerja adalah carpal tunnel syndrome (CTS) (Kao, 2003).

CTS adalah suatu sindrom yang timbul akibat nervus medianus tertekan di dalam terowongan carpal yang terdapat di pergelangan tangan, sewaktu nervus medianus berjalan melewati terowongan tersebut dari lengan bawah ke tangan (Hudaya, 2002). Sindrom ini diartikan dengan tanda dan gejala yang dihasilkan dari kompresi saraf medianus pada pergelangan tangan. CTS mengakibatkan rasa tidak nyaman dan nyeri, terbatasnya aktifitas keseharian, kurang tidur dan ketidakmampuan untuk bekerja (Levine dkk, 1993 dikutip oleh Kostopoulos, 2003).

Penyebab utama CTS sering sangat sukar ditentukan, apakah karena kondisi kerja atau karena suatu penyakit. Pada banyak pasien dengan CTS, penyebab dasar dari keluhan tidak dapat ditemukan. Penggunaan tangan yang berhubungan dengan hobi, seperti pekerjaan rumah tangga (menjahit, merajut, menusuk, memasak), kesenian, dan olah raga. Beberapa penelitian melaporkan bahwa lebih dari separuh penyebab CTS adalah faktor di tempat kerja.

Teknologi fisioterapi untuk intervensi untuk mengatasi CTS dengan salah satu cara manual yang cukup efektif adalah mobilisasi saraf. Mobilisasi saraf adalah teknik manipulatif dimana jaringan saraf digerakkan dan diulurkan baik gerakan yang relatif terhadap sekitarnya (interface yang mekanis) atau dengan pengembangan ketegangan (Nurfitriyah, 2013).

Myofascial release (MFR) mengacu pada teknik pijat, petunjuk untuk peregangan fasia dan melepaskan ikatan antara fasia dan integumen, otot, tulang, dengan tujuan untuk menghilangkan rasa sakit, meningkatkan jangkauan gerak dan menyeimbangkan tubuh. MFR adalah teknik jaringan lunak menggunakan 
tangan yang memfasilitasi hamparan ke fasia dibatasi. Sebuah tekanan berkelanjutan diterapkan ke dalam jaringan terbatas, setelah 90-120 detik jaringan akan mengalami perubahan panjang histologi yang memungkinkan myofascial release pertama yang dirasakan. Terapis melakukan rilis pada penghalang jaringan.

\section{METODE PENELITIAN}

Metode yang dipergunakan dalam penelitian ini, yaitu menggunakan metode kuantitatif dengan jenis quasi experiment. Rancangan penelitian yang dipergunakan adalah two group pre test and post test control design. Penelitian ini menggunakan dua kelompok, yang digunakan untuk menganalisis pengaruh pemberian mobilisasi saaf dan MFR untuk mengurangi nyeri pada pasien CTS. Kelompok I diberikan intervensi berupa mobilisasi saraf, kelompok II diberikan intervensi berupa MFR.

Penelitian ini di laksanakan di poli fisioterapi RSUD Dr.Moewardi Surakarta. Waktu penelitian di laksanakan bulan Juni sampai dengan Juli 2016.

Subjek penelitian merupakan semua pasien yang didiagnosis CTS yang datang ke poli fisioterapi RSUD Dr. Moewardi Surakarta Kriteria inklusi penelitian ini adalah: (1) pasien yang didiagnosis CTS oleh dokter, (2) pasien yang positif salah satu diantara phalen, tinel, prayer test.

Kriteria eksklusi (1) pasien post operasi peregangan ligamentum carpi transversum, (2) pasien berusia diatas 70 tahun, (3) pasien memiliki cedera akut pada lengan. Kriteria drop out adalah subjek yang tidak memenuhi jumlah sesi terapi sebanyak 2 kali.

Jumlah subyek penelitian adalah 15 orang dengan diagnosis CTS yang dibagi dalam dua kelompok perlakuan. Kelompok I diberikan mobilisasi saraf sebanyak 8 orang dan kelompok II diberikan MFR sebanyak 7 orang. Sebelum diberikan mobilisasi saraf dan MFR seluruh subyek penelitian diberikan inFra merah.

Penilaian derajat nyeri menggunakan quadruple Visual analoge scale (VAS). Quadruple VAS yang terbagi menjadi 4 penilaian kriteria nyeri yaitu : nyeri saat ini, nyeri rata-rata selama 24 jam terakhir, nyeri paling ringan dan nyeri paling berat. Penggunaan alat ukur quadruple VAS sama seperti VAS yaitu berupa sebuah garis lurus dengan panjang $10 \mathrm{~cm} / 100 \mathrm{~mm}$.

\section{HASIL PENELITIAN}

Tabel 1

Karakteristik Subyek Penelitian

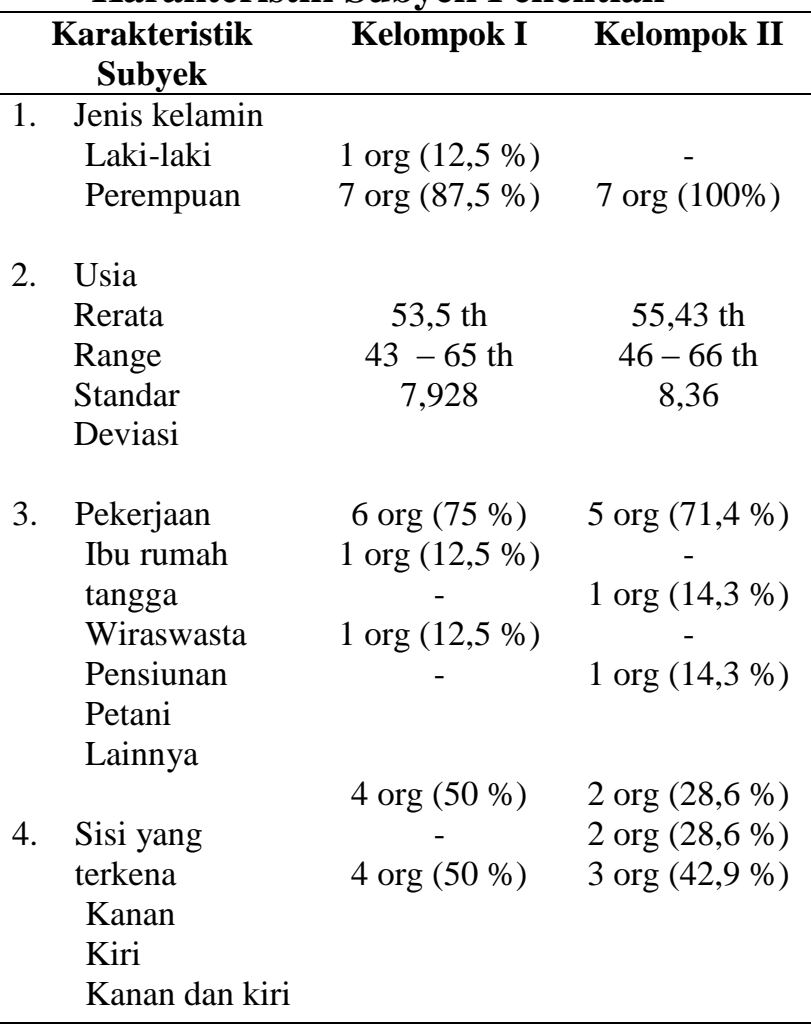


Tabel 2

Hasil Pengukuran Nyeri Sebelum Diberikan Perlakuan

\begin{tabular}{lcc}
\hline \multicolumn{1}{c}{$\begin{array}{c}\text { Nyeri } \\
\text { sebelum } \\
\text { diberikan } \\
\text { perlakuan }\end{array}$} & $\begin{array}{c}\text { Kelompok } \\
\text { I }\end{array}$ & Kelompok II \\
\hline Rata-rata & 6,125 & \\
Range & $4,850-$ & $4,250-7,075$ \\
Std. & 7,675 & 1,186 \\
Deviation & 1,108 & \\
\hline
\end{tabular}

\section{Tabel 3}

Hasil Pengukuran Nyeri Setelah Diberikan Perlakuan

\begin{tabular}{lcc}
\hline $\begin{array}{c}\text { Nyeri setelah } \\
\text { diberikan } \\
\text { perlakuan }\end{array}$ & $\begin{array}{c}\text { Kelompok } \\
\text { I }\end{array}$ & Kelompok II \\
\hline Rata-rata & 4,462 & 3,346 \\
Range & $1,875-$ & $2,00-6,250$ \\
Std. Deviation & 6,675 & 1,538 \\
& 1,500 & \\
\hline
\end{tabular}

Uji beda nyeri sebelum perlakuan antara kelompok I dan kelompok II menggunakan Mann-Whitney diperoleh hasil nilai probabilitas (p) sebesar 0,121 (p $>0,05$ ). Hal ini menunjukkan bahwa tidak ada perbedaan yang bermakna nilai nyeri sebelum perlakuan antara kelompok I dan kelompok II.

Uji beda nyeri sebelum dan sesudah perlakuan pada kelompok I dengan Wilcoxon didapat nilai probabilitas $(p)=0,012 \quad(p<0,05)$. Hal ini menunjukkan bahwa terdapat perbedaan yang signifikan antara nilai pengukuran sebelum perlakuan dan setelah perlakuan pada kelompok I. Rata-rata nyeri sebelum perlakuan 6,125 dan setelah perlakuan 4,462 . Hal ini bererti terdapat penurunan nyeri sebesar 2,1 .

Uji beda Uji beda nyeri sebelum dan sesudah perlakuan pada kelompok II dengan Wilcoxon. didapat nilai probabilitas $(p)=0,018(p<0,05)$. Hal ini menunjukkan bahwa terdapat perbedaan yang signifikan antara nilai pengukuran sebelum perlakuan dan setelah perlakuan pada kelompok II. Rata-rata nyeri sebelum perlakuan 5,257 dan setelah perlakuan 3,346 . Hal ini bererti terdapat penurunan nyeri sebesar 1,9 .

Uji beda nyeri setelah perlakuan antara kelompok I dengan kelompok II dengan analisis Mann-Whitney. nilai probabilitas $(p)=0,189(\mathrm{p}>0,05)$. Hal ini menunjukkan bahwa tidak terdapat perbedaan nyeri yang signifikan setelah perlakuan antara kelompok I dan kelompok II. Kedua kelompok menunjukkan pengaruh yang sama. Bila dilihat dari perbedaan pengurangan nyeri sebelum dan sesudah perlakuan pada setiap kelompok diperoleh data yaitu kelompok I pengurangan nyeri sebesar 2,1 dan kelompok II sebesar 1,9. Meskipun kelompok I menunjukkan pengurangan nyeri yang lebih banyak tetapi secara statistik tidak menunjukkan perbedaan yang bermakna.

\section{PEMBAHASAN}

Pada penelitian ini disimpulkan bahwa mobilisasi saraf dan MFR dapat menurunkan nyeri pada penderita CTS. Intervensi diberikan 2 kali perminggu selama 3 minggu. Hasil ini sejalan dengan beberapa penelitian lain. Berdasarkan pada penelitian yang dilakukan oleh TalAkabi, dkk 2000 dengan judul An Investigation to Compare The Effectiveness of Carpal Bone Mobilisation and Neurodynamic Mobilisation As Methods of Treatment for Carpal Tunnel Syndrome di Swiss. Hasil yang didapat dari penelitian tersebut adalah mobilisasi saraf dapat menurunkan nyeri pada CTS. 
Penelitian dengan judul Perbandingan Kombinasi Ultrasound dan Mobilisasi Saraf dengan Kombinasi Ultrasound dan Myofacial Release untuk Mengurangi Nyeri pada Sindrom Terowongan Karpal yang dilakukan oleh Permadi, dkk (2014) di Universitas Udayana Bali. Penelitian eksperimental ini dengan rancangan randomized pre test and post test group design. Sampel sebanyak 22 orang dibagi menjadi dua kelompok masing-masing 11 orang. Kelompok perlakuan I diberikan kombinasi ultrasound dan neural mobilization, sedangkan kelompok perlakuan II diberikan kombinasi ultrasound dan myofascial release. Pengukuran derajat nyeri menggunakan Boston Carpal Tunnel Questionnaire pada pemeriksaan awal dan dievaluasi setelah diberikan perlakuan pertama dan setiap dua minggu sekali. Hasil penelitian didapatkan selisih mean sebelum dan sesudah perlakuan pada kelompok I yaitu $0.891 \pm 0.234$ dengan hasil uji paired test didapatkan nilai $\mathrm{p}=0.000 \quad(\mathrm{p}<0.05)$. Sedangkan pada kelompok II didapatkan selisih mean sebelum dan sesudah perlakuan yaitu $0.925 \pm 0.209$ dengan hasil uji paired test didapatkan nilai $\mathrm{p}=0.000$ $(\mathrm{p}<0.05)$. Dari hasil tersebut dapat disimpulkan bahwa mobilisasi saraf bisa menurunkan nyeri pada CTS.

Pada penelitian yang dilakukan oleh Kostopoulos (2003) mobilisasi saraf yang dilakukan selama 4 minggu dengan dosis 3 set dengan 10 repetisi tiap set didapatkan hasil yang menunjukan bahwa mobilisasi saraf berpengaruh terhadap penurunan nyeri pada CTS. Byl dkk (2002) pada studi cadaver meneliti strain dari saraf medianus sepanjang ekstremitas atas yang digunakan para dokter untuk mengevaluasi disfungsi saraf. Data menunjukan bahwa ULTT 1 menghasilkan regangan maksimal saraf medianus ada lorong karpal sebesar 7,6\% dengan peningkatan regangan terbesar selama posisi siku ekstensi, yaitu sebesar 3,5\%. Mobilisasi saraf juga dapat mengembalikan keseimbangan dinamis antara gerakan relatif dari jaringan saraf dan interface mekanik di sekitarnya sehingga memungkinkan tekanan intrinsik pada jaringan saraf akan menjadi optimal (Shacklock, 1995).

Tahun 1998 Yologlu dkk membandingkan antara pemberian, (1) mobilisasi saraf dan splinting pada wrist, (2) mobilisasi saraf dengan US, (3) serta mobilisasi saraf, splinting dan US terhadap nyeri pada penderita CTS di mana didapatkan pada kelompok 2 memberikan hasil yang lebih baik. Mobilisasi saraf memiliki efek langsung pada konduksi saraf yang diukur dengan pemeriksaan elektrofisiologi, sehingga memberikan bukti untuk memasukkan mobilisasi saraf sebagai intervensi dalam neurodynamics yang berubah pada saraf perifer (Kumar dkk, 2013).

Penelitian lain yang dilakukan oleh Akalin dkk (2002) yang membandingkan mobilisasi saraf, mobilisasi tendon dan splinting dengan splinting saja selama 4 minggu. Secara statistik terdapat penurunan nyeri yang signifikan pada kedua kelompok, tetapi kelompok mobilisasi saraf, mobilisasi tendon dan splinting lebih baik daripada kelompok splinting dalam menurunkan nyeri.

Namun di penelitian lain yang dilakukan oleh Marcioli dkk (2013) dengan membagi secara acak menjadi kelompok I (kontrol), kelompok II (mobilisasi saraf selama 1 menit), dan kelompok III (mobilisasi saraf selama 3 menit) didapatkan hasil bahwa mobilisasi 
saraf tidak efektif sebagai pengobatan konservatif pada kompresi saraf medianus.

Pada penelitian ini bila dilihat perbedaan mana yang lebih baik antara mobilisasi saraf dan MFR diketahui tidak terdapat perbedaan. Meskipun pengurangan nyeri pada pemberian mobilisasi saraf lebih besar dari pada MFR tetapi secara statistik tidak terdapat perbedaan yang signifikan. Perlakuan selama 3 minggu belum bisa membedakan mana yang lebih baik antara mobilisasi saraf dan MFR. Hal ini dimungkinkan karena perubahan pada regenerasi saraf disebabkan keadaan CTS yang sudah kronis, faktor usia, menopause, pekerjaan yang melakukan gerakan repetitif pada tangan dan kompresi pada saraf medianus yang sudah dalam derajat berat. CTS terjadi bila saraf medianus mengalami kompresi dalam struktur anatomis terowongan karpal. Kompresi dapat disebabkan oleh meningkatnya volume dalam terowongan karpal, pembesaran saraf medianus, atau berkurangnya area cross-sectional dalam terowongan karpal. Dari ketiga penyebab ini, yang menjadi penyebab terbanyak adalah meningkatnya volume terowongan karpal, namun apa yang menjadi penyebab peningkatan volume ini masih belum jelas hingga saat ini. Diduga salah satu penyebab adalah tenosinovitis akibat trauma berulang (Phallen, 1975).

Aktivitas selama penelitian tidak bisa dikendalikan. Gerakan flexi-extensi berulang dan terus menerus pada pergelangan tangan dan jari-jari akan meningkatkan tekanan pada tendon yang mengakibatkan terjadinya tenosinovitis dan selanjutnya menyebabkan kompresi pada saraf medianus. Kompresi ringan pada saraf tepi akan menurunkan aliran darah epineural. Transport aksonal akan terganggu, akibat kompresi aksonal tekanan dalam endoneural akan meningkatkan dan menyebabkan parestesia.

\section{KESIMPULAN DAN SARAN}

Bedasarkan hasil penelitian yang telah diuraikan, maka dapat diambil kesimpulan sebagai berikut : (1) mobilisasi saraf dapat menurunkan nyeri pada pasien CTS, (2) MFR dapat menurunkan nyeri pasien CTS (3) tidak terdapat perbedaan antara mobilisasi saraf dan MFR untuk menurunkan nyeri pada pasien CTS.

Saran dari penelitian ini adalah (1) perlu dilakukan penelitian yang lebih lanjut lagi tentang pengaruh mobilisasi saraf terhadap penurunan nyeri pada CTS dalam jumlah subjek yang lebih banyak atau dengan desain penelitian deskriptif atau time series, (2) untuk kriteria inklusi lebih baik pada CTS yang unilateral, (3) disarankan untuk meminimalkan faktor perancu seperti pemberian obat-obatan serta aktivitas subjek perlu dibatasi

\section{DAFTAR RUJUKAN}

Akalin E, El O, Peker O, et al, 2002; Treatment of carpal tunnel syndrome with nerve and tendon gliding exercises; Am. J. Phys. Med. Rehabil 2002;81:108-113

Kostopoulos D. 2003, Treatment Of Carpal Tunnel Syndrome: A Review Of The Non-Surgical Approaches With Emphasis In Neural Mobilization; Journal of Bodywork and Movement Therapies, 8, 2-8

Kumar V, Goyal M, Rajendran N, Narkeesh. 2013; Effect Of Neural Mobilization On Monosynaptic 
Reflex - A Pre Test Post Test Experimental Design; International Journal of Physiotherapy and Research, Int $J$ Physioth Res (3):58-62.

Permadi, Andayani, Indrayani. 2014, Perbandingan Kombinasi Ultrasound dan Mobilisasi Saraf dengan Kombinasi Ultrasound dan Myofacial Release untuk Mengurangi Nyeri pada Sindrom Terowongan Karpal, Universitas Udayana, Bali

Phalen GS. 1975; The Carpal Tunnel Syndrome, Seventeen Years Experience in Diagnosis and Treatment of Six Hundred FiftyFour Hands; The Journal of Bone and Joint Surgery 48A(2): $211 \pm 228$

Tal-Akabi. A and Ruhston. A., 2000; An Investigation To Compare Effectivenes of Carpal Bone Mobilisation And Neurodynamic Mobilisation as Methods of Treatment For Carpal Tunnel Syndrome; Harcourt Publisher Ltd, Manual Therapy (2000) 5(4), $214 \pm 222$

Yologlu S, Kahyan A, dkk, 1998; Comparison of three conservative treatment protocols in carpal tunnel syndrome, Journal compilation department of physical medicine and rehabilitation, department of neurology, department of orthopedics and traumatology, department of biostatistics, Inonu University, Malatya, 